\title{
Formulation and In-Vitro Evaluation of Buclizine Buccoadhesive Tablets
}

\author{
Sandeep Ashokrao Wathore * \\ MUPS College of Pharmacy (B.Pharm), Degaon-444506, Dist.Washim (MS), India
}

\begin{abstract}
Buclizine is an antihistamine that is used to treat motions sickness, especially to prevent and treat symptoms such as abdominal pain, dizziness, nausea, vomiting, headaches, etc. It may also be used either alone or in a combination with other medicines for the treatment of hay fever and other allergic conditions. These dosages form make close contact with buccal mucosa, avoid first- pass metabolism, increase absorption and patient compliance, results in an enhanced drug bioavailability. Buccal adhesive tablets were prepared by direct compression. Carbopol 940 and Sodium Alginate was used in different ratios and also in combination. Formulated 10 batches were evaluated for physical parameter swelling studies, bioadhesion studies, and in-vitro drug release and in-vitro drug permeation. Bioadhesion studies were carried out to determine mucoadhesive potential of prepared tablets. Tablets were evaluated for in-vitro drug release for 6 hrs, using USP type II method and. From these results it can be concluded that formulation batch F6 was most promising comprising of 1:4 ratio of Sodium Alginate. The best fit model for the optimized batch F6 was zero order having R value 0.9889 and K value is 0.2542 .
\end{abstract}

Keywords: Buclizine, Carbopol 940, Sodium Alginate, buccal tablet, in-vitro drug permeation

Article Info: Received 10 July 2019; Review Completed 19 August 2019; Accepted 25 August 2019; Available online 30 Aug 2019

Cite this article as:

Wathore SA, Formulation and In-Vitro Evaluation of Buclizine Buccoadhesive Tablets, Journal of Drug Delivery and Therapeutics. 2019; 9(4-A):137-144 http://dx.doi.org/10.22270/jddt.v9i4-A.3430

*Address for Correspondence:

Sandeep Ashokrao Wathore, MUPS College of Pharmacy (B.Pharm), Degaon-444506, Dist.Washim (MS), India

\section{INTRODUCTION}

Amongst the various routes of drug delivery, oral route is perhaps the most preferred to the patient and the clinician alike. However, per oral administration of drugs has disadvantages such as hepatic first pass metabolism and enzymatic degradation within the GI tract, that prohibit oral administration of certain classes of drugs especially peptides and proteins. Consequently, other absorptive mucosa is considered as potential sites for drug administration [1,2]. Transmucosal routes of drug delivery (i.e., the mucosal linings of the nasal, rectal, vaginal, ocular, and oral cavity) offer distinct advantages over per oral administration for systemic drug delivery $[3,4]$. These advantages include possible bypass of first pass effect, avoidance of presystemic elimination within the GI tract, and, depending on the particular drug, a better enzymatic flora for drug absorption. The nasal cavity as a site for systemic drug delivery has been investigated by many research groups. However, the potential irritation and the irreversible damage to the biliary action of the nasal cavity from chronic application of nasal dosage forms, as well as the large intra- and inter-subject variability in mucus secretion in the nasal mucosa, could significantly affect drug absorption from this site $[5,6]$. The objective of present work was to design mucoadhesive buccal drug delivery system in the form of buccal tablet by using different bioadhesive polymers like carbopol 940, sodium alginate which are not used individually or in combination with Buclizine, that could be applied to buccal mucosa to release the drug in buccal cavity and to increase the bio-availability of the Buclizine by decreasing the metabolism in GIT and liver, try to reduce dosing frequency and to improve patient compliance.

\section{MATERIALS AND METHODS}

Buclizine was obtained as gift sample by Mankind Pharma Ltd.Mumbai. India. Carbopol $940 \mathrm{P}$ and Sodium alginate was obtained as a gift sample from S.D.Fine Chem Ltd., Mumbai. All other materials and solvents used were of analytical grade.

\section{Experimental Formulation of Buccoadhesive Tablets of Buclizine:}

All the ingredients are weigh accurately and passed through the sieve no. 100. Then all the ingredients were mixed according to decreasing order of their weight. The buccoadhesive tablets were prepared by using Carbopol 940, Sodium alginate at 1:2, 1:4, 1: 6 and 1:8 and in combination 1:1, 1:2 drug: polymer ratio were prepared. The buccoadhesive tablets were prepared with selected polymers by direct compression on 8 station tablet 
compression machine using $7 \mathrm{~mm}$ punch. Accurately weighed quantities of drug and other ingredients viz. polymers such as CP 940P, Sodium alginate, Lactose, Talc and Magnesium stearate, Sodium saccharine were mixed by triturating in a glass mortar-pestle. The blend was directly compressed at weight of $120 \mathrm{mg}$ using flat-faced $7 \mathrm{~mm}$ diameter punch. The compositions of the formulation batches containing different polymers in various ratios are specified in table no.1.

\section{Micromeritics evaluation of powder blends}

The micromeritic evaluation of the powder blends was done by calculating angle of repose, bulk density, tapped density, and Carr's index (\% compressibility), Hausner's ratio.

\section{Evaluation of buccoadhesive tablets of Buclizine}

\section{Thickness}

The thickness of the tablets was determined using a micrometer screw gauge. Five tablets from each formulation were evaluated and average values were calculated [9].

\section{Hardness}

For each type of formulation, the hardness value of 3 tablets was determined using Monsanto hardness tester [10].

\section{Weight variation test}

For weight variation, 20 tablets of each type of formulation were weighed individually on an electronic balance, average weight was calculated and individual tablet weight was then compared with the average value to find out the deviation in weight. The $\%$ weight variation also calculates [11].

\section{Uniformity content}

\section{Standard solution}

Weigh accurately about $10 \mathrm{mg}$ of Buclizine standard and transfer it into a $100 \mathrm{ml}$ volumetric flask. Then add $70 \mathrm{ml}$ of ethanol \& dissolved it by mechanical shaking then Volume was made upto $100 \mathrm{ml}$ with ethanol. The solution was filtered through whatman filter paper. First few $\mathrm{ml}$ of the filtrate was discarded. $5 \mathrm{ml}$ of the filtrate was diluted to 20 $\mathrm{ml}$ with ethanol so as to get final concentration of $25 \mu \mathrm{g} / \mathrm{ml}$ [12].

\section{Test solution}

Content uniformity was determined by placing one tablet in a $100 \mathrm{ml}$ volumetric flask. Then add $70 \mathrm{ml}$ of ethanol \& dissolved it by mechanical shaking then volume was made up to $100 \mathrm{ml}$ with ethanol. The solution was filtered through Whatman filter paper. First few $\mathrm{ml}$ of the filtrate was discarded. $5 \mathrm{ml}$ of the filtrate was diluted to $20 \mathrm{ml}$ with ethanol so as to get final concentration of $25 \mu \mathrm{g} / \mathrm{ml}$. The absorbance of the resulting solution was recorded at 238 nm.

\section{Surface pH of the tablet}

The surface $\mathrm{pH}$ of the tablet is measure by placing tablet into the distilled water for $2 \mathrm{hrs}$ in the petri plate and after 2 $\mathrm{hr}$ tablet was removes from the distilled water and surface $\mathrm{pH}$ of tablet measure by $\mathrm{pH}$ paper $[13,14]$.

\section{In- vitro swelling index studies}

The swelling rate of buccoadhesive tablets was determined using a phosphate buffer $\mathrm{pH}$ 6.8. The tablets were weighed individually and placed separately in watch glass containing $4 \mathrm{ml}$ of phosphate buffer $\mathrm{pH}$ 6.8. At regular intervals (30 min, 1,2 and 6 hours) the tablets were removed from the watch glass and excess surface water was removed using the filter paper. The swollen tablets were then reweighed and swelling index (SI) was calculated using following formula [15]. $\mathrm{SI}=\mathrm{W} 2-\mathrm{W} 1 \times 100$

W1

$$
\begin{aligned}
& \text { Where, W1 ---------- Initial weight of tablet } \\
& \text { W2 ---------- Weight of swollen tablet. }
\end{aligned}
$$

\section{Ex-Vivo mucoadhesion time}

The Ex-vivo Mucoadhesion time is examine after application of buccal tablet on freshly cut sheep buccal mucosa. The fresh buccal mucosa is tied on the glass slide and tablet wetted with one drop of $\mathrm{pH} 6.8$ phosphate buffers and pasted to mucosa by applying a light force with fingertip. Then the slide is put in beaker containing $200 \mathrm{ml}$ of phosphate buffer and keep at $37 \pm 10 \mathrm{C}$ after 2 minute a slow stirring is apply to stimulate buccal cavity environment and tablet adhesion is record for 12 hrs. The time require for detaching tablet from buccal mucosa is record as a mucoadhesion time [16].

\section{Measurement of adhesion force}

Gout buccal mucosa was used as the model membrane. It was obtained from slaughterhouse. The underlying buccal tissues were separated and washed thoroughly with phosphate buffer solution $\mathrm{pH}$ 6.8. It was then tied to the lower side of glass vial using thread. The tablet to be tasted was stuck on the mucosal surface. It was kept undisturbed for 3 minutes. Then the weights on right side of pan were slowly added in an increment of 0.2 gm till the tablet just separated from the membrane surface. The excess weight on the right pan i.e. total weight minus $2 \mathrm{gm}$ was taken as measure of the bioadhesive strength. Bioadhesive force was calculated by using following equation [17]. Bioadhesive force $(\mathrm{N})=$ Bioadhesive Strength $\mathrm{X} 9.81$

100

\section{In-vitro drug release studies}

Standard USP dissolution apparatus was used to study the in-vitro release profiles using rotating paddle method. Invitro release study of buccoadhesive tablets of Simvastatin was carried out using USP type II apparatus (Paddle method) at $50 \mathrm{rpm}$. Each tablet was stuck at the bottom of flask so that drug could be released only from upper face of tablet. Medium used for the release rate study was $500 \mathrm{ml}$ phosphate buffer solution pH 6.8 with $0.5 \%$ dodecyl sodium sulphate. During the course of study the assembly was maintained at $37 \pm 0.2 \mathrm{oC}$. The sample was withdrawn; $5 \mathrm{ml}$ at time interval of 15,30 , and 45 minutes upto 6 hours and replaced with $5 \mathrm{ml}$ of fresh dissolution method. The amount of Buclizine released was determined spectrophotometrically at $238 \mathrm{~nm}$ [18].

\section{In vitro drug permeation}

The in vitro buccal drug permeation study of Buclizine through the sheep buccal mucosa was performed using Keshary-Chien type glass diffusion cell at $37-\mathrm{C} \pm 0.2$-C. Fresh Porcine buccal mucosa was mounted between the donor and receptor compartments. The buccal tablet was placed on to the mucosa and the compartments clamped together. The donor compartment was filled with $1 \mathrm{~mL}$ of phosphate buffer $\mathrm{pH}$ 6.8. The receptor compartment (15-mL capacity) was filled with phosphate buffer $\mathrm{pH} 6.8$, and the hydrodynamics in the receptor compartment was maintained by stirring with a magnetic bead at $50 \mathrm{rpm}$. A 1$\mathrm{mL}$ sample was withdrawn at predetermined time intervals and analyzed for drug content at $238 \mathrm{~nm}$ using an UV Spectrophotometer [19]. 


\section{FTIR studies}

The infrared spectrum of pure Buclizine was recorded and spectral analysis was done. The dry sample of the drug was thoroughly mixed with potassium bromide and directly placed in the sample holder. The drug-excipients interaction study was carried out by using FTIR to determine the molecular interaction between polymer and drug. All physical mixtures and drug sample were mixed with dried KBR in ratio $1: 100$. Then small fraction of mixture was compressed on automatic IR Press (Kimaya Engg. Thane, India) at pressure 10 tones to form transparent pellet. Then the IR spectrum of pellet was taken on FTIR spectrophotometer (Schimadzu, 8400S, Japan) [20, 21].

\section{Kinetic modeling}

To analyze the mechanism of release and release rate kinetics of the dosage form, the data obtained were fitted into Zero order, First order, Higuchi matrix, Peppas and Hixson Crowell model using PCP-DISSO - v2 software $[22,23]$.

\section{Accelerated Stability Studies}

Accelerated stability testing of prepared formulation batch was carried out to determine the stability of drug and carrier and also to determine the physical stability of formulation under accelerated storage condition at various temperatures $[24,25]$. The prepared tablets were placed in borosilicate screw capped glass containers. The samples were kept at condition of $45^{\circ} \mathrm{C}+20 \mathrm{C} / 70 \%+5 \mathrm{RH}$ and were analyzed at 60 th, 120 th and 180 days for their changes in drug content.

\section{RESULT AND DISCUSSION}

The FT-IR spectra of the pure Buclizine and physical mixture of drug and polymers were recorded to check interaction between drug and polymers. The characteristic peaks of Buclizine were appeared in the spectra without any remarkable change in the position. This indicated that there was no chemical interaction between Buclizine and polymers. The bulk density obtained for all the formulations in the range of $0.528-0.739$ and the true density in the range of $0.650-0.913$. The Angle of repose of the powder blend of all the formulations were found to be in range of 27.56-30.500 which is in the good or in the acceptable range means showing the good flowability necessary for proper flow of powder blend into the die cavity. The Carr's index of the powder blend of all the formulations were found to be in the range of $18.72-21.91$ which is good or in the acceptable range means they shows good or fair flowability for proper flow of powder blend. The hausner's ratio was found to be in the range of $1.13-1.28$. Results was shown $n$ table no.2. All tablet shows permissible properties Diameter of all tablets were found to be $8.22 \pm 0.02 \mathrm{~mm}$. The hardness of tablets was found to be 3.5 to $4.24 \mathrm{~kg} / \mathrm{cm} 2$. It was found that hardness was increased with increase in the proportion of polymers. The lowest hardness was obtained in formulations containing sodium alginate. Thicknesses of tablets were found to be in the range of $3.30-4.20 \mathrm{~mm}$ Formulations containing Carbopol were found to be thicker than other formulations as the Carbopol is fluffy in nature. All the tablets shows \% friability in the range of $0.70-0.90 \%$ which is within the limit. All the formulations pass the Weight variation test as all tablets within the range limit for weight variation. The surface $\mathrm{pH}$ of the tablets was found to be in the range of $5-7$. All the formulations complies the test for Uniformity of content as it found to be within the limit of
$85 \%-115 \%$. The bioadhesion and drug release profile are dependent upon swelling behavior of the tablets. Swelling index was calculated with respect to time. Swelling index increased as the weight gain by the tablets increased proportionally with the rate of hydration. From the results shown in Figure no. 7 it is conclude that appropriate swelling behavior of the buccal adhesive system is an essential property for uniform release of drug and effective mucoadhesion. The rate and extent of swelling increased with an increasing concentration of polymer in the formulation. The maximum swelling index was observed in formulations containing Carbopol 940 as it is hydrophilic in nature and absorbs solution rapidly. The maximum swelling was attained at the 4 to 5 hrs after that tablet starts to erode slowly. The Sodium Alginate also absorbs solution but shows low swelling index than Carbopol 940. From the results shown in Fig.no.8 it is conclude that the bioadhesion characteristics were found to be affected by the nature and proportion of the bioadhesive polymers used. The maximum Bioadhesive force was observed in the formulations, F1 to F4, which contains Carbopol 940 in four different ratios, Bioadhesive force was found to increase with increase in proportion of Carbopol 940.The reason for such high bioadhesion force of Carbopol 940 might be ionization of Carbopol 940 at salivary $\mathrm{pH}$ which leads to improved attachment of the tablet to mucosal surface. The formulation F5 to F8 containing Sodium Alginate in four different ratios shows bioadhesive force less than Carbopol 940.The bioadhesive force is increasing in these formulations as the polymer concentration increases as observed in case of Carbopol 940..The Mucoadhesion time were found to increase with the increase in polymer concentration The mucoadhesion time in formulations containing Sodium Alginate was found to be lower than formulation containing Carbopol 940. The formulation F1 containing carbopol in 1:2 ratios gives the greater release than $\mathrm{F} 1, \mathrm{~F} 2$ and $\mathrm{F} 3$ because of lower concentration of carbopol. As the concentration of Carbopol 940 increase in the formulations causes a slower release profile this finding may be due to the stronger binding and cohesion force between the particles. Due to this the drug release get slower and did not released within 6 hrs. In this finding the formulations containing sodium alginate gives the better release of drug as compare to formulations containing carbopol.In the formulations F5 to F8 the F6 gives the highest release of drug than formulations F5,F7 and F8 which contains the sodium alginate in 1:4 ratio. Whereas the formulation F8 gives the lower release of the drug as compare to formulations F5, F6, F7 which contains the sodium alginate in 1:8 ratio The results of dissolution studies indicated that the release was varied according to the type and ratio of the polymer used. Formulation batch F6 containing sodium alginate in 1:4 ratio has shown maximum percent of drug release $88.79 \%$ over the period of $6 \mathrm{hrs}$, of Simvastatin buccal tablet. The optimized batch F6 was studied for in-vitro permeation study. The results showed that $80.10 \%$ drug was permeated in $6 \mathrm{hrs}$. The in vitro release data was applied to various kinetic models to predict the drug release kinetic mechanism shown in table no.22. The best fit model for the optimized batch F6 is zero order having $\mathrm{R}$ value 0.9889 and $\mathrm{K}$ value is 0.2542 . The stability studies of the buccoadhesive tablets revealed that no significant changes in the physical parameters when stored at storage temperature of $450 \mathrm{C}$ and at room temperature. No significant reduction in the content of the active drug was observed over a period of 180 Days hence shelf life of the formulation could extrapolate to a minimum of two years. 
Table 1. Composition of Buclizine buccoadhesive tablets

\begin{tabular}{|c|c|c|c|c|c|c|c|c|c|c|}
\hline Ingredients (mg) & F1 & F2 & F3 & F4 & F5 & F6 & F7 & F8 & F9 & F10 \\
\hline Buclizine & 10 & 10 & 10 & 10 & 10 & 10 & 10 & 10 & 10 & 10 \\
\hline Carbopol 940 & 20 & 40 & 60 & 80 & -- & -- & -- & -- & 10 & 20 \\
\hline Sodium Alginate & -- & -- & -- & -- & 20 & 40 & 60 & 80 & 10 & 20 \\
\hline Sod. Saccharine & 0.12 & 0.12 & 0.12 & 0.12 & 0.12 & 0.12 & 0.12 & 0.12 & 0.12 & 0.12 \\
\hline Lactose & 85.8 & 65.8 & 45.8 & 25.8 & 85.8 & 65.8 & 45.8 & 25.8 & 85.8 & 65.8 \\
\hline Mag. Stearate & 2 & 2 & 2 & 2 & 2 & 2 & 2 & 2 & 2 & 2 \\
\hline Talc & 2 & 2 & 2 & 2 & 2 & 2 & 2 & 2 & 2 & 2 \\
\hline Total wt. & 120 & 120 & 120 & 120 & 120 & 120 & 120 & 120 & 120 & 120 \\
\hline
\end{tabular}

Table 2. Physical parameters of buccoadhesive tablets

\begin{tabular}{|c|c|c|c|c|c|}
\hline Formulations & $\begin{array}{l}\text { Bulk Density* }( \pm \\
\text { SD) }\end{array}$ & $\begin{array}{l}\text { Tapped Density* } \\
( \pm \text { SD) }\end{array}$ & $\begin{array}{ll}\text { Angle } & \text { of } \\
\operatorname{Repose}(\theta & \end{array}$ & Carr's Index & Hausner's Ratio \\
\hline F1 & $0.687 \pm 0.04$ & $0.855 \pm 0.02$ & 29.25 & 19.64 & 1.28 \\
\hline $\mathrm{F} 2$ & $0.677 \pm 0.03$ & $0.863 \pm 0.03$ & 30.50 & 21.49 & 1.27 \\
\hline F3 & $0.660 \pm 0.05$ & $0.838 \pm 0.05$ & 29.25 & 21.24 & $1 . .26$ \\
\hline F4 & $0.739 \pm 0.04$ & $0.913 \pm 0.06$ & 30.25 & 19.07 & 1.23 \\
\hline F5 & $0.659 \pm 0.05$ & $0.844 \pm 0.02$ & 27.56 & 21.91 & 1.28 \\
\hline F6 & $0.620 \pm 0.03$ & $0.783 \pm 0.04$ & 29.25 & 20.71 & 1.26 \\
\hline F7 & $0.576 \pm 0.04$ & $0.713 \pm 0.04$ & 29.21 & 19.25 & 1.13 \\
\hline F8 & $0.528 \pm 0.03$ & $0.650 \pm 0.04$ & 30.25 & 18.72 & 1.23 \\
\hline F9 & $0.650 \pm 0.04$ & $0.835 \pm 0.04$ & 29.15 & 18.60 & 1.14 \\
\hline F10 & $0.655 \pm 0.05$ & $0.840 \pm 0.05$ & 30.40 & 19.15 & 1.20 \\
\hline
\end{tabular}

Table 3. Physical parameters of formulation batches of buccoadhesive tablets

\begin{tabular}{|c|c|c|c|c|c|c|c|}
\hline Formulations & $\begin{array}{l}\text { Hardness } \\
(\mathrm{kg} / \mathrm{cm} 2)^{*}( \pm \mathrm{SD})\end{array}$ & $\begin{array}{l}\text { Thickness } \\
(\mathrm{mm})^{*}( \pm \mathrm{SD})\end{array}$ & \% Friability & $\begin{array}{l}\text { Avg. } \\
\text { Weight* }\end{array}$ & $\begin{array}{l}\% \mathrm{Wt} \\
\text { Variation }\end{array}$ & $\begin{array}{l}\text { Surface } \\
\mathrm{pH}\end{array}$ & $\begin{array}{l}\text { Uniformity of } \\
\text { Content* }\end{array}$ \\
\hline F1 & $3.5 \pm 0.163$ & $3.51 \pm 0.028$ & 0.75 & 121.4 & $-4.40-3.00$ & $6-7$ & $97.33 \pm 1.46$ \\
\hline F2 & $3.6 \pm 0.163$ & $3.71 \pm 0.028$ & 0.75 & 120.6 & $-3.81-4.41$ & $6-7$ & $99.29 \pm 2.45$ \\
\hline F3 & $3.8 \pm 0.115$ & $3.80 \pm 0.05$ & 0.70 & 120.7 & $-3.02-3.60$ & $6-7$ & $100.46 \pm 2.95$ \\
\hline F4 & $4.4 \pm 0.191$ & $4.20 \pm 0.036$ & 0.75 & 120.9 & $-4.09-4.17$ & $6-7$ & $98.26 \pm 1.24$ \\
\hline F5 & $3.4 \pm 0.081$ & $3.60 \pm 0.011$ & 0.80 & 119.8 & $-3.17-2.67$ & $5-6$ & $99.26 \pm 2.45$ \\
\hline F6 & $3.6 \pm 0.125$ & $3.56 \pm 0.05$ & 0.90 & 120.9 & $-2.43-3.44$ & $5-6$ & $98.26 \pm 1.20$ \\
\hline F7 & $3.9 \pm 0.163$ & $3.44 \pm 0.026$ & 0.85 & 119.4 & $-4.52-2.17$ & $6-7$ & $101.23 \pm 2.19$ \\
\hline F8 & $4.1 \pm 0.191$ & 3.300 .028 & 0.70 & 120.9 & $-4.09-3.34$ & $5-6$ & $99.25 \pm 2.46$ \\
\hline F9 & $3.4 \pm 0.081$ & $4.20 \pm 0.036$ & 0.85 & 120.9 & $-2.43-3.44$ & $5-6$ & $99.26 \pm 2.45$ \\
\hline F10 & $3.6 \pm 0.163$ & $3.80 \pm 0.05$ & 0.85 & 119.4 & $-4.52-2.17$ & $6-7$ & $98.26 \pm 1.20$ \\
\hline
\end{tabular}


Table 4. Effect of polymers on bioadhesive strength, bioadhesive force and mucoadhesion time of formulation batches of buccoadhesive tablets

\begin{tabular}{|l|l|l|l|}
\hline Formulations & Bioadhesive Strength $(\mathrm{gm})^{*}( \pm$ SD) & Bioadhesive Force(N)* \pm SD) & Mucoadhesion Time (Hr) $( \pm$ SD $)$ \\
\hline F1 & $6.8 \pm 1.3$ & $0.667 \pm 0.127$ & $12 \pm 0.50$ \\
\hline F2 & $9.3 \pm 1.5$ & $0.912 \pm 0.147$ & $14 \pm 0.65$ \\
\hline F3 & $15.4 \pm 1.45$ & $1.510 \pm 0.142$ & $17 \pm 0.60$ \\
\hline F4 & $20.6 \pm 1.55$ & $2.020 \pm 0.152$ & $20 \pm 0.46$ \\
\hline F5 & $4.8 \pm 1.4$ & $0.470 \pm 0.137$ & $9 \pm 0.34$ \\
\hline F6 & $6.5 \pm 1.1$ & $0.637 \pm 0.107$ & $11 \pm 0.41$ \\
\hline F7 & $8.8 \pm 1.25$ & $0.863 \pm 0.117$ & $12 \pm 0.36$ \\
\hline F8 & $11.4 \pm 1$ & $1.118 \pm 0.098$ & $15 \pm 0.21$ \\
\hline F9 & $6.6 \pm 1.4$ & $0.665 \pm 0.126$ & $11 \pm 0.45$ \\
\hline F10 & $4.6 \pm 1.3$ & $0.450 \pm 0.137$ & $10 \pm 0.38$ \\
\hline
\end{tabular}

Table 5. Kinetic modeling

\begin{tabular}{|l|l|l|l|}
\hline Formulations & Best Fit Model & R & K \\
\hline F1 & Peppas & 0.9897 & 3.0037 \\
\hline F2 & Peppas & 0.9809 & 1.5301 \\
\hline F3 & Peppas & 0.9905 & 0.8732 \\
\hline F4 & Peppas & 0.9975 & 0.9252 \\
\hline F5 & Hix.Crow. & 0.9944 & -0.0010 \\
\hline F6 & Zero Order & 0.9889 & 0.2542 \\
\hline F7 & Zero Order & 0.9945 & 0.2350 \\
\hline F8 & Hix.Crow. & 0.9964 & -0.0011 \\
\hline F9 & Peppas & 0.9797 & 3.0027 \\
\hline F10 & Peppas & 0.9809 & 1.4023 \\
\hline
\end{tabular}

Table 6. Accelerated Stability studies for optimized batch F6

\begin{tabular}{|l|l|l|l|l|}
\hline Parameters & Initial & 60 Days & 120 Days & 180 Days \\
\hline Colour & White & No Change & No Change & No Change \\
\hline Hardness(kg/cm2) & $3.6 \pm 0.125$ & $3.6 \pm 0.081$ & $3.6 \pm 0.056$ & $3.5 \pm 0.163$ \\
\hline Drug Uniformity (\%) & $98.26 \pm 1.20$ & $98.24 \pm 1.15$ & $98.22 \pm 1.05$ & $97.21 \pm 1.02$ \\
\hline$\%$ DrugRelease & 88.79 & 88.15 & 87.50 & 87.05 \\
\hline
\end{tabular}

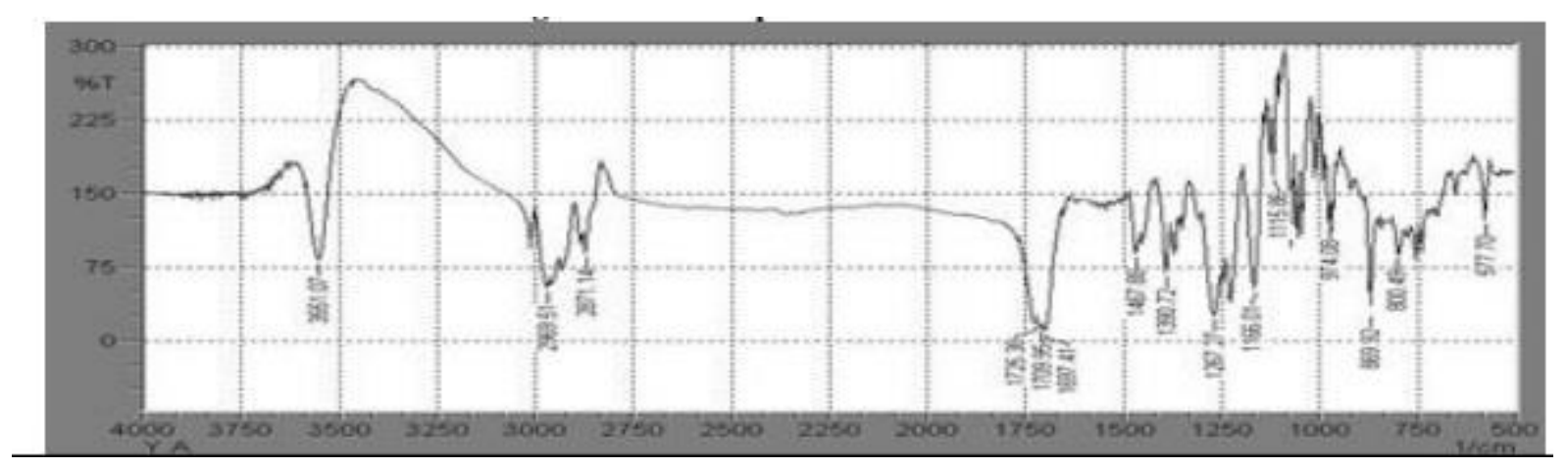

Figure 1. FT-IR spectrum of Buclizine 


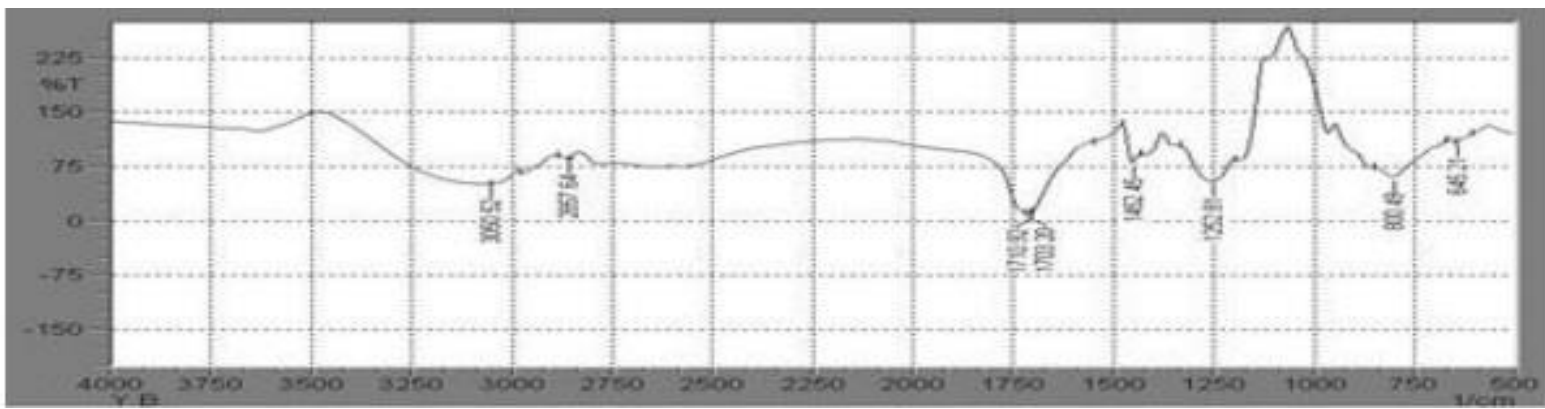

Figure 2. FT-IR spectrum of carbopol 940

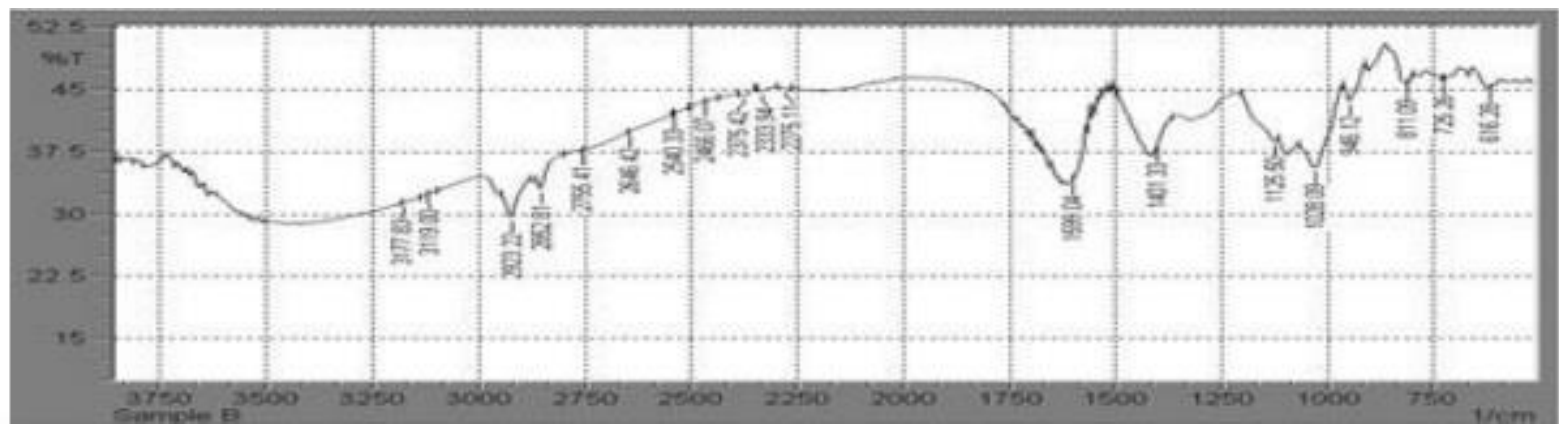

Figure 3. FT-IR spectrum of sodium alginate

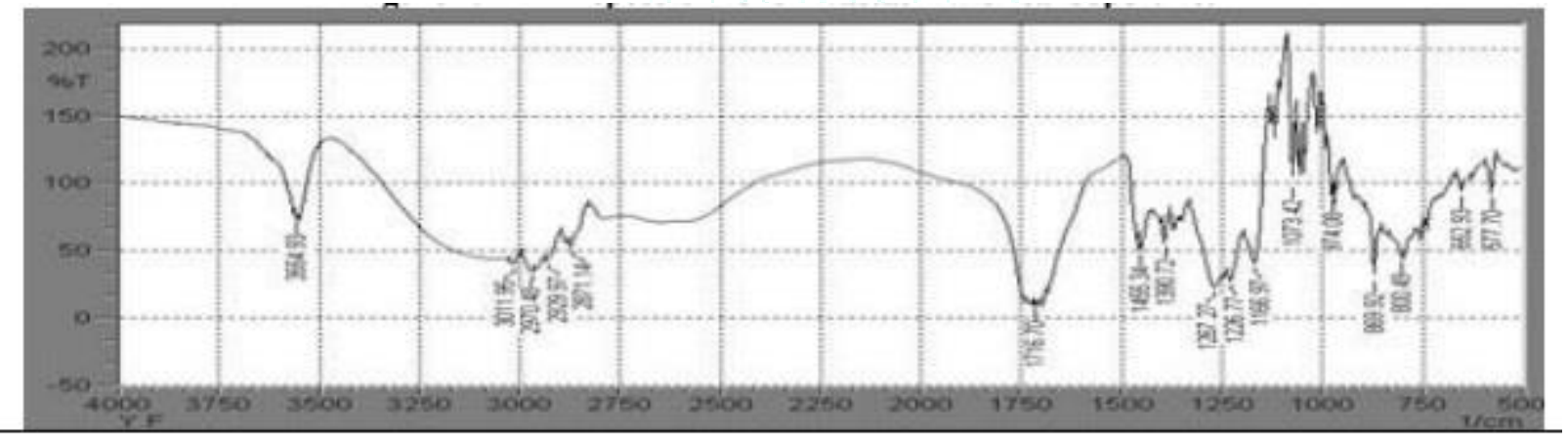

Figure 4. FT-IR spectrum of Buclizine with carbopol 940.

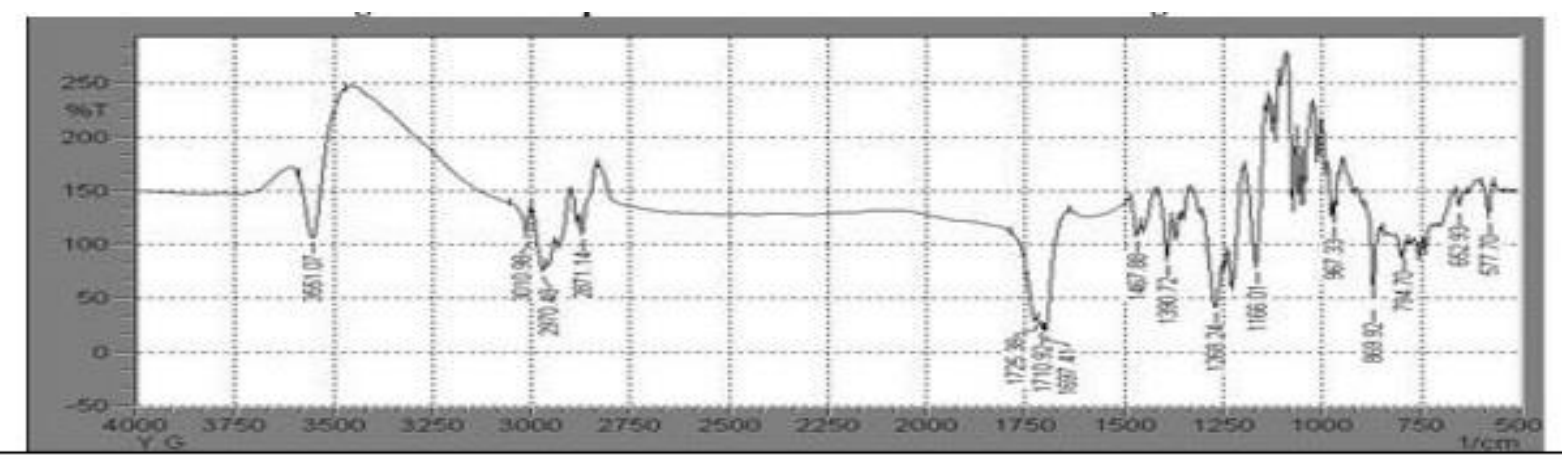

Figure 5. FT-IR spectrum of Buclizine with sodium alginate.

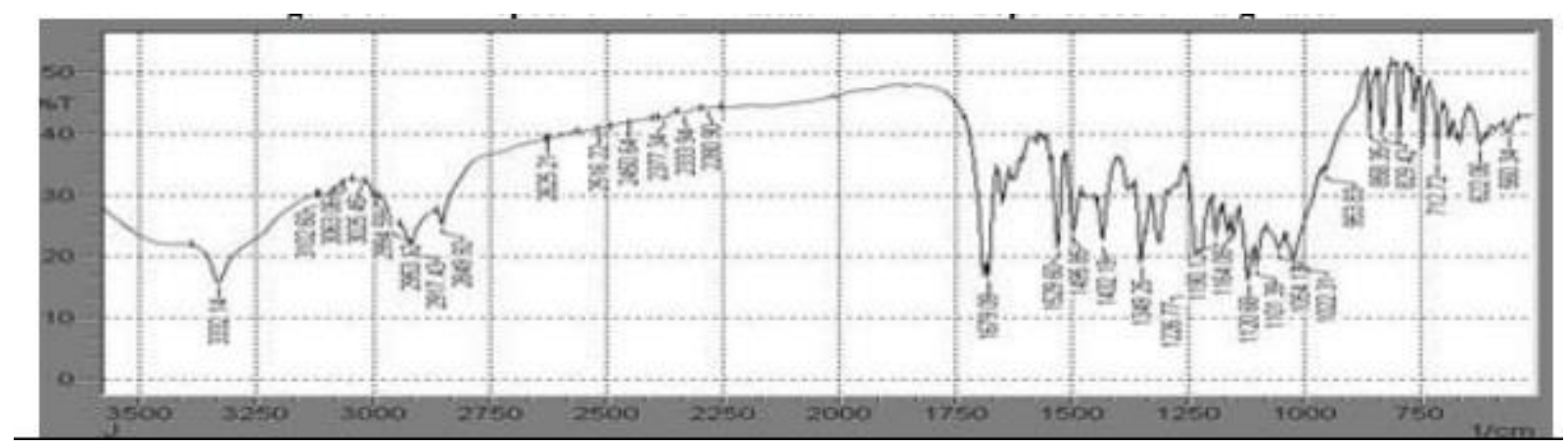

Figure 6. FT-IR spectrum of Buclizine with carbopol \& sodium alginate 
Figure 7. \% Swelling index of formulations F1 to F10 containing Combination of polymers.

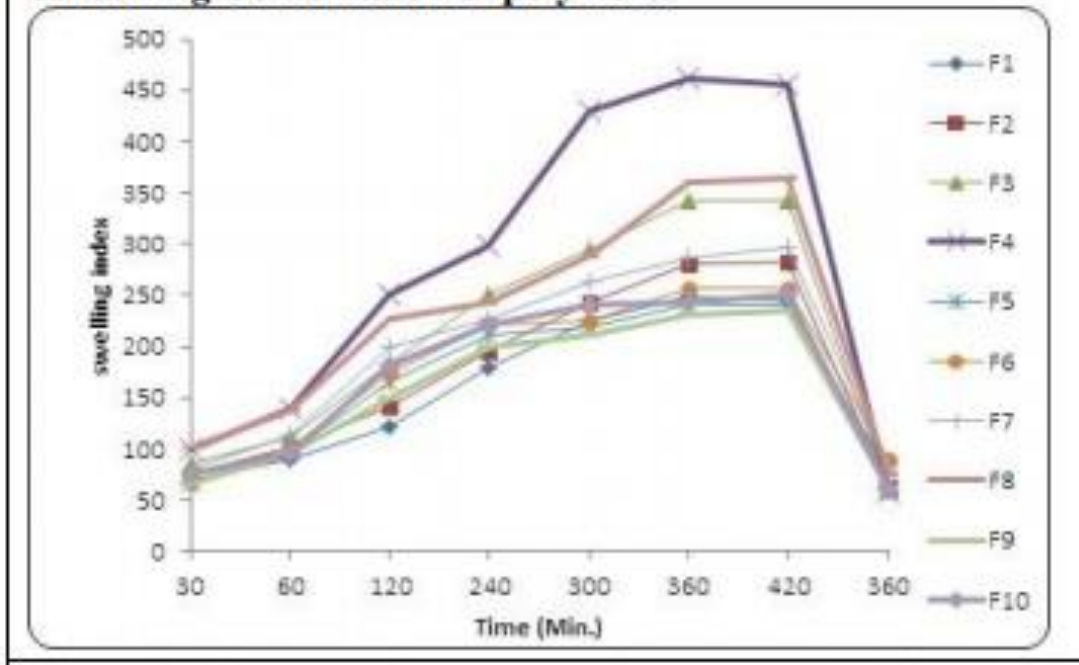

Figure 8. Effect of various polymers on bioadhesive force for formulations F1-F10

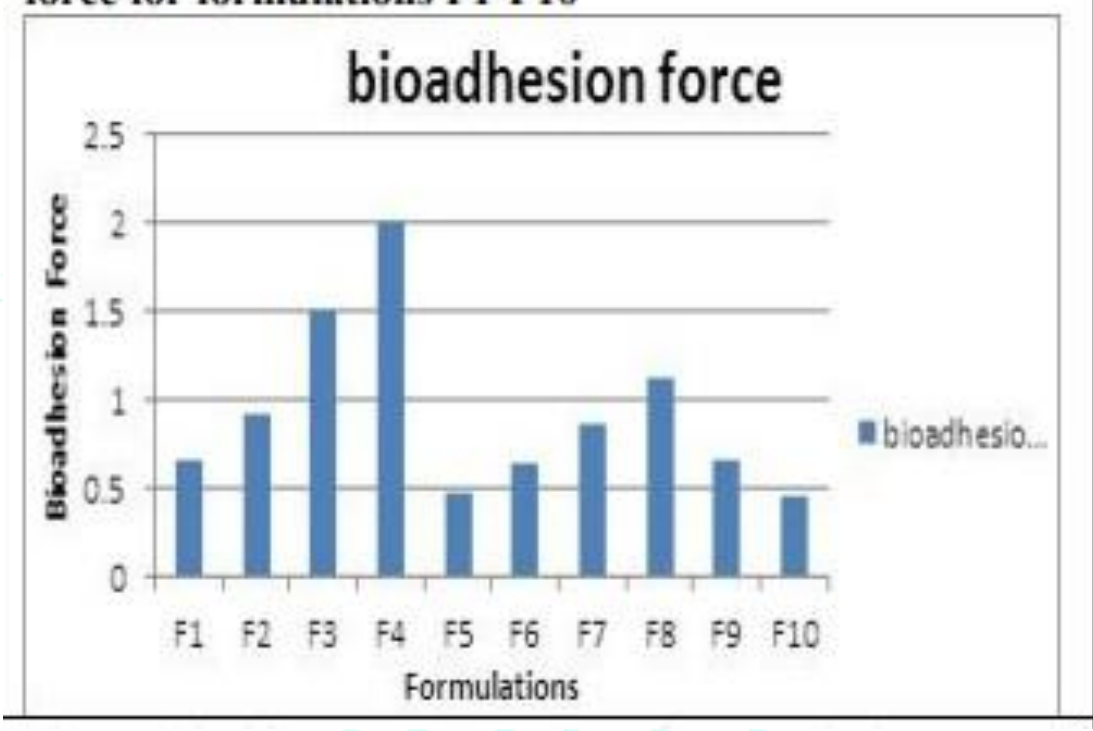

Figure 9. \% cumulative Release of batches F1to F10.

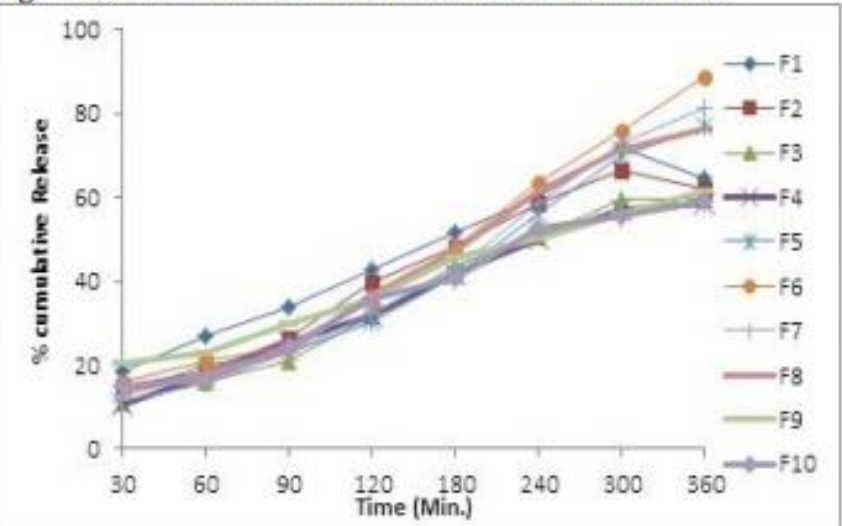

Figure 10. \% Drug permeated of the optimized batch F6.

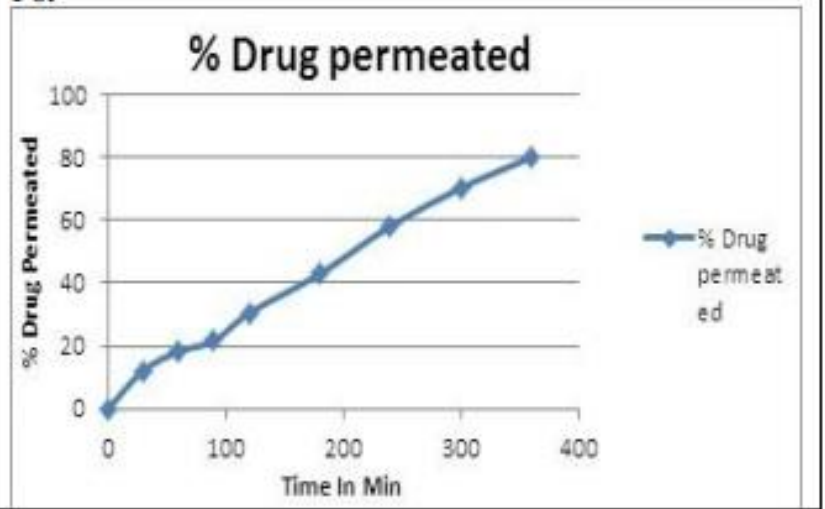




\section{CONCLUSION}

The results of the present study indicate that buccal tablets of Buclizine with controlled drug release can be successfully prepared by direct compression method using Carbopol 940 and Sodium Alginate as mucoadhesive polymers The formulation $\mathrm{F} 6$ the drug matrix composition 1:4 ratio of Sodium Alginate was found to be promising, which shows an in vitro drug release of $88.79 \%$ in $6 \mathrm{hrs}$ along with satisfactory bioadhesion strength $(6.5 \pm 1.1 \mathrm{~g})$. The in vitro release kinetics studies reveal that the best fit model for the optimized batch F6 is zero order having R value 0.9889 and $\mathrm{K}$ value is 0.2542 . So buccal tablet of Buclizine were encouraging, and it need for further study for reproducibility. Therefore Buclizine can be given by this route for better availability and can be minimized side effects of drugs.

\section{REFERENCES}

1. Gupta A, Garg S, Khar RK. Mucoadhesive buccal drug delivery system-A review. Indian drugs, 29, 1992, 586-593.

2. Brahmankar DM, Jaiswal SB. Biopharmaceutics and Pharmacokinetics a treatise, Chapter no.8, 1 st edition. New Delhi, Vallabh Prakashan, 2005, 335-371.

3. Thakare VM, Jadhao UT, Tekade BW, Chaudhari KP, Mandore PS. Design and Evaluation of Mucoadhesive Atorvastatin Calcium tablet using surface response methodology. Int J Pharm Pharm Sci, 5(4), 2013, 474-480.

4. Natr MK, Chien YW. Development of anticandial delivery system (II) mucoadhesive devices for prolonged drug delivery in the oral cavity. Drug Dev Ind Pharm, 22, 1996, 243-253.

5. Squier CA, Cox P, Wertz PW. Lipid content and water permeability of skin and oral mucosa. The J Invest Dermat, 96, 1991, 123-126.

6. Rathbone M, Drummond B and Tucker I. Oral cavity as a site for systemic drug delivery. Adv Drug Del Rev, 13, 1994, 1-22.

7. Clarke's, Analysis of Drug and Poisons, vol-1, Third edition, 2005, 1561.

8. Wilson \& Gisvald's, Textbook of Organic medicinal and Pharm Chem. Eleventh edition. 955. 9. Martin A, Swarbrik G. Physical pharmacy, physical chemical principal of pharmaceutical sci. 3rd ed. Varghese publication house, 1991, 518-519.

10. Aulton ME. Pharmaceutics, The science of dosage form design, 2nd Edn, Churchill Livingstone, New York, 2002, 290-291.
11. Banker SG, Anderson RN, Tablets, Lachman L, Liberman AH, Kanig LJ, 1991, Text book of the theory and practice of industrial pharmacy, 3rd Edn, Mumbai, Varghese Publication House, 317-324.

12. Swamy KS, Goud BA, Kumar PV. Bioadhesive Buccal Tablets of Simvastatin, Journal of Advance Pharm Sci, 1(1), 2011, 29.

13. Tekade BW, Jadhao UT, Thakare VM, Chaudhari KP. Formulation Development and Evaluation of Mucoadhesive Tablet Containing Citrizine Dihydrochloride using Different Mucoadhesive Polymers. Am J of Pharma Research, 3(8), 2010, 6009- 6019.

14. Ayyappan T, Kasture PV. Development and in vitro evaluation of a buccoadhesive ondansetron hydrochloride tablet formulation. Indian drugs, 43(2), 2005, 92-95.

15. Goud K, Desai H, Pramodkumar TM. Preparation and evaluation of a Novel buccal adhesive system. AAPS Pharm Sci Tech, 5(3), 2004, 1-9

16. Patel VM, Prajapati BG, Patel HV, Patel KM. Mucoadhesive bilayer tablets of propranolol hydrochloride. AAPS Pharm Sci Tech, 8(3), 2007, E1-E6.

17. Nakhat PD, Kondawar AA, Babla IB, Rathi LG, Yeole PG. Studies on buccoadhesive tablets of Terbutaline sulphate. Indian J Pharm Sci, 2008, 505-510

18. Tehrani MR, Jazayer G, Toliyat T, Bayati K, Khalkhali K, Shamimi K, Miremadi A, Dorkoosh FA. Development and invitro evaluation of novel buccoadhesive tablet formulation of prednisolone. Acta Pharm, 52, 2002, 121-127.

19. Tsutsumi K, Obata Y, Nagai T, Loftsson T, Takayama K. Buccal absorption of ergotamine tartarate using the bioadhesive tablet system in guinea pigs. Int J Pharm, 238, 2002, 161-170

20. Williams WD. Infrared Spectrophotometry. In, Beckett. J B, Stenlake, JB, (Eds.), Practical Pharmaceutical Chemistry, third edition, Vol 2, CBS Publishers and Distributors, 1990, 331336. 21. Jeffery GH, Bassett J, Mendham J, Denney RC.Vogel's Textbook of quantitative chemical analysis, fifth ed, ELBS, London,1991, 741-757

22. Higuchi. Mechanism of sustained action medicament, Theoretical analysis of rate release of solid drugs dispersed in solid matrices. J Pharmsci, 52, 1963, 1145-1149.

23. Korsmeyer RW, Gunny R, Peppas NA, Mechanism of solute release from porous hydrophilic polymers, Int J Pharmaceutics, 15, 1983, 25-35.

24. Kennon K. Use of models in determining chemical pharmaceutical stability. J Pharm Sci, 53, 1964, 815-818.

25. Yoshioka S, Stella VJ. Stability of drug and dosage form. Kluwer academic publishers, New York, 2002, 223-224 